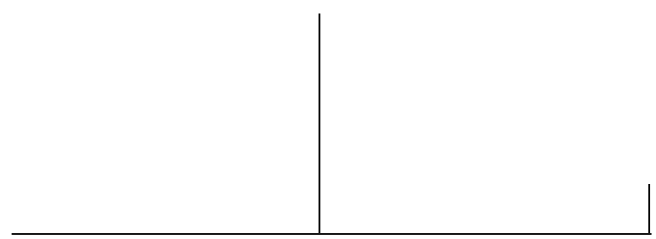

Rev. Latinoam. Psicopat. Fund., São Paulo, 16(2), 335-338, jun. 2013

A anatomia da melancolia. Vol. III - A Segunda Partição - A cura da melancolia Robert Burton Curitiba: Editora UFPR, 2012.

\title{
A anatomia da melancolia - A segunda partição - A cura da melancolia
}

Roberto Kirschbaum

O terceiro volume da edição brasileira de $A$ anatomia da Melancolia de Robert Burton traz a segunda partição da obra de 1621: "A cura da Melancolia". O autor inicia admitindo que a melancolia é dificilmente curável, mas aponta, em seguida, que ela pode ser muito mitigada e abrandada, com a condição de que o doente "esteja disposto a ser auxiliado". Esta condição, presente ainda hoje nas psicoterapias das correntes mais respeitáveis, aponta ainda para uma diferença fundamental e atual de noção-de-homem e noção-de-mundo destas para com as do modelo médico hegemônico vigente, segundo o qual a cura das doenças é possível mesmo sem a participação do doente, bastando para tanto a participação unilateral dos fármacos. 
Sendo Burton teólogo e vigário, demonstra uma preocupação ética na sua discussão sobre a eficiência e a legitimidade do uso de curas ilegais e proibidas, curas "por meios diabólicos, comumente praticados pelo Demônio e por seus ministros, feiticeiras, bruxas, magos etc." (p. 13), ou, como nos esclarece o tradutor, as curas mágicas ou do oculto segundo o pensamento da época. A discussão é lúcida, dando voz a diversos autores que concordam ou não com sua eficiência ou com a legitimidade de seu uso. Dentre os que reconhecem a eficiência dessas curas há, talvez surpreendentemente, Santo Agostinho (bispo, escritor, teólogo, filósofo, 354-430) que, segundo Burton, infere que elas chegam a "resultados estupendos e admiráveis; nós vemos apenas os efeitos, mas não as causas" (p. 15). É útil mais uma vez o esclarecimento do tradutor sobre a crença da época, segundo a qual "apenas Deus realiza milagres; todo o mais seria apenas ilusão ou resultado de um conhecimento da natureza, por parte dos demônios ou magos" (p. 15), assim que tais curas não passariam de um ato natural. Burton menciona ainda que elas foram publicamente professadas em importantes universidades como a de Salamanca na Espanha e a de Cracóvia na Polônia, sendo subsequentemente condenadas em 1318 pelo chanceler da Universidade de Paris. Após o breve apanhado histórico sobre a utilização de curas do oculto para a melancolia, posiciona-se contrário a seu uso. Outras discussões éticas têm lugar no livro, por exemplo uma discussão sobre a propriedade do uso da astrologia na cura da melancolia.

O autor passa então a expor sobre as "curas legítimas primeiramente por Deus". Nessa discussão expõe suas facetas teológica e médica (ainda que não fosse médico, era competente autodidata), apontando para a necessidade do emprego tanto da prece quanto da medicina, "não uma sem a outra, mas ambas juntas" (p. 18). Numa época em que a religião era muito mais influente do que é hoje, sua consideração para com a ciência, sem com isto desconsiderar a religião, é digna de nota. No capítulo "médico, paciente, medicina", manifesta sua preocupação com o fato de que alguns médicos, guiados por avidez, mediquem desnecessariamente. Este tema continua bastante atual: o Conselho Federal de Farmácia manifestou recentemente sua preocupação com a banalização do uso de medicamentos "por meio de estratégias mercadológicas de ampliação de vendas"; considere-se também o surgimento de superbactérias com o uso indiscriminado de antibióticos. Lembra-nos Burton, com Arnaldo de Vilanova (1238-1311), importante médico do mundo latino medieval: "Um médico sábio não aplica remédio senão em caso de necessidade" (p. 27).

Dentre as curas indicadas para a melancolia, algumas são do senso comum: ao falar da retificação da dieta, Burton cita inúmeros autores que defendem ou atacam este ou aquele tipo de alimento ou bebida, bem como discute sobre as quan- 
tidades a serem ingeridas, a mastigação e vários outros aspectos da alimentação. Fala também de exercícios, esportes, caminhadas pela manhã, banhos diversos (aos quais dedica algumas páginas), e não deixa de lado a prática sexual moderada: "Vênus desmesurada e excessiva pode ser uma causa, bem como sua ausência" (p. 48).

Em certo ponto prescreve o estudo, a dedicação ao aprendizado de alguma arte ou ciência como sendo o melhor remédio para a melancolia - exceto, é claro, para os melancólicos cuja moléstia provenha do excesso de estudo. Com Sêneca (filósofo romano, 4 aC.-65 dC.) lembra que "tal como o alimento para o corpo, assim a leitura para a alma" (p. 125). Traz, dentre muitas outras, a contribuição do alquimista, médico e filósofo persa Rásis, figura importante na Era Dourada Islâmica (ca. 865 dC.-925 dC.), que recomenda "um colóquio contínuo aos melancólicos" e também "que os leve a sério, discuta com eles e por vezes cavile e contenda" (p. 125) - o que nos lembra da "cura pela fala", termo cunhado por Anna O. e que até hoje é utilizado para denominar as psicoterapias. Além disso, prescreve as conversas com amigos, e a música.

Burton dedica boa parte deste tomo a uma "digressão consolatória", uma fala reconfortante para ajudar o leitor a lidar com melancolia devida a descontentamentos de diversas origens, tais como "deformidade do corpo, doença, vileza por nascimento, descontentamentos peculiares" (p. 176), "pobreza, carestia e outras adversidades" (p. 192), "servidão, perda de liberdade, aprisionamento, exílio" (p. 231), "tristeza pela morte de amigos ou outros, medos em vão" (p. 235), "inveja, livor, emulação, ódio, ambição, amor-próprio e todas as outras afecções" (p. 250). A abrangência é ainda maior do que é possível citar aqui.

Finalmente, Robert Burton dedica a última parte do livro à "Pharmaceutice, o gênero da medicina que cura por medicamentos" (p. 277). Dentre estes, alterativos, ervas, outros vegetais e suas dosagens, purgantes de vários tipos, e também métodos como vários tipos de sangria, inclusive com o uso de sanguessugas. Estes métodos obsoletos não fazem do livro uma leitura obsoleta; ao contrário, trata-se de uma janela privilegiada e panorâmica para a história, cultura, psicologia, medicina e outras ciências no séc. XVII, bem como suas diversas influências.

\section{Referências}

Burton, R. (2012). A anatomia da melancolia (Vol. III). Curitiba: Editora UFPR.

Conselho Federal de Farmácia (CFF): Manifesto "Conselho Federal de Farmácia (CFF) é contra a liberação dos medicamentos isentos de prescrição (MIPs) para fora do 
balcão das farmácias e drogarias”. Recuperado em 26 de julho de 2012 do: <http:/ /crfsp.org.br/images/arquivos/2012_07_13_mips_cff.pdf>.

Wikipédia: a enciclopédia livre. Recuperado de: 〈http://en.wikipedia.org/wiki/>.

\section{RoBERTo KiRschbaum}

Psicólogo e psicanalista; Mestrando pelo Programa de Estudos Pós-Graduados em Psicologia Clínica da Pontifícia Universidade Católica de São Paulo - PUC-SP (São Paulo, SP, Br) sob orientação do Prof. Dr. Manoel Tosta Berlinck; bolsista do Conselho Nacional de Desenvolvimento Científico e Tecnológico - CNPq (Brasília, DF, Br)

Rua Veríssimo Glória, 165

01251-140 São Paulo, SP, Br

Fone: (11) 2935-8310

e-mail: robertokir@gmail.com 